\title{
スマートソサエティを支える高機能電子部品材料 High-performance Electronic Components and Materials for Smart Society
}

\author{
嶋田 勇三 \\ Yuzo SHIMADA \\ ナミックス株式会社 \\ Namics Corporation
}

IoT，AI，ロボットなどに代表される技術革新は，我々の 生活，社会を大きく変えようとしています。このような超ス マート社会を実現するためには，エレクトロニクス機器の高 速高性能化, 小型化, 高信頼化を飛躍的に達成することが求 められています。特に，デバイス・材料・部品技術，自動運 転のためのセンサーデバイス，レーダ，アンテナ，通信技 術, 車載用耐熱部品材料, 実装技術などが極めて重要です. また電子機器の熱・電気・応力設計からマテリアルインフォ マティックス材料設計までを含めた技術開発が必要になって います。そこで，近い将来実現されるスマートソサイエティ に向けた電子部品材料を対象に周辺技術を含めた講演特集を (一社) エレクトロニクス実装学会協賛のもと企画しました。

本特集では 1 件の特別講演, 22 件の招待講演, 4 件の受賞 記念講演を含めた 34 件の講演を 7 セッションに分けて実施 しました。

第 1 セッションは，最近注目されている材料として，熱電 材料と負の熱膨張を持つ材料を取り上げました。受賞講演は 積層型熱電変換素子の特性と応用，招待講演では，世界最高 性能を示すバルク熱電材料の開発やプロセス検討, 応用展開 について発表されました。また，負の熱膨張材料では作成方 法や熱的性質について興味深い発表がありました。

第 2 セッションは, パワーデバイス関連と新機能材料の発 表でした． 特別講演ではパワーエレクトロニクスのための銀 粒子接合技術，招待講演ではパワーデバイス用酸化ガリウム やプロセス開発，機能性ナノシートデバイス，貫通型多孔粒 子の開発について紹介がありました．新しいデバイスの可能 性を感じます.

第 3 セッションは，圧電材料を中心とした材料開発から応 用としてのセンサを含めた各種デバイスの開発を取り上げま した． 3 件の招待講演は，“無鉛圧電セラミックスの作成と 特性向上”, “圧電体による低周波超音波帯振動を利用したセ ンサ”，“5Gのスマートフォン向けフィルタ材料”です。ま た，高感度のにおいセンサや振動センサなどの一般講演もあ りました。受賞講演では, “圧電セラミックス材料の技術開 発”をテーマに過去からの幅広い紹介がありました。
第 4 セッションは，電子材料の基礎から加工プロセスの最 適化, 電気化学特性, 誘電体特性, 機械的性質などについて の研究報告がありました。また，受賞講演として“サイアロ ン蛍光体の特性向上と実用化”の発表がありました。電子材 料の着実な技術開発が進められており，応用展開への期待を 感じます.

第 5 セッションは, 新材料としてのナノ粒子, グラフェン, 多孔質球状粒子の開発及び応用展開を取り上げました。受 賞講演は，“半導体デバイス接合用ナノ銀ペーストの開発実 用化”についてです。また，招待講演ではグラフェンナノデ バイス技術によるセンサ／スイッチ，グラフェンの高スルー プット合成, ジルコニアセンサ技術について発表がありました.

第 6 セッションは, 招待講演 3 件で，5G に向けた材料開 発，デバイス開発について取り上げました。 GHz 帯用フェ ライト材料の開発動向や高速高周波に対応した放熱用の高熱 伝導 AlN ウィスカーフィラーの開発，さらには $5 \mathrm{G}$ を実現す るミリ波フェーズドアレイ無線機について発表がありまし た. 第 5 世代移動通信システム（5G）はスマートソサエティ に不可欠なテクノロジーです。

第 7 セッションは，最近積極的に取り組まれている計算科 学，マテリアルインフォマティックス技術について 4 件の招 待講演がありました。 マテリアルインフォマティックスを 使った材料設計，スマート化への試み，新材料開発など幅広 く研究開発されています。また，第一原理計算によるセラ ミックス材料研究も紹介され，わが国のこの分野でのレベル の高さを改めて感じることが出来ました.

以上のように材料から部品デバイス，プロセス，システム までの広範な領域からの興味ある講演がありました。また， 材料設計や性能設計のためのマテリアルインフォマティック ス技術を含め，将来のエレクトロニクスを支える重要な技術 発表があり，多くの質問や活発な議論が行われました。会場 は，2 日に亘り，60-80名と多くの聴講者の参加がありまし た. 材料技術で世界をリードする我が国の最先端電子部品材 料技術を紹介でき，スマートソサエティを実現する技術とし て貢献できるものと確信しています。 